\title{
Broadleaf Weed Control and Cabbage Seed Yield following Herbicide Application
}

\author{
Kassim Al-Khatib ${ }^{1}$, Carl Libbey ${ }^{2}$, and Sorkel Kadir ${ }^{3}$ \\ Mount Vernon Research and Extension Unit, 1468 Memorial Highway, Mount \\ Vernon, WA 98273-9788
}

Additional index words. clopyralid, metolachlor, oxyfluorfen, pendimethalin, pyridate, trifluralin

\begin{abstract}
Broadleaf weed control with trifluralin, oxyfluorfen, pendimethalin, clopyralid, pyridate, and metolachlor in cabbage (Brassica oleracea $L$.) grown for seed was evaluated. No single herbicide controlled broadleaf weeds adequately, with the exception of pendimethalin at 1.92 and $3.84 \mathrm{~kg}$ a.i./ha. However, combinations of trifluralin + oxyfluorfen, pendimethalin + clopyralid, and oxyfluorfen + pyridate effectively controlled weeds and did not reduce seed yields. Herbicides caused slight to moderate injury symptoms to cabbage plants, with the greatest injury caused by pendimethalin and the least by trifluralin and metolachlor. However, plants recovered from these symptoms and appeared normal at the bud stage. None of the herbicides applied alone or in combinations adversely affected cabbage population, height, or flowering date. Chemical names used: 3,6-dichloro-2-pyridinecarboxylic acid (clopyralid); 2-chloro- $N$-(2-ethyl-6-methylphenyl)$N$-(2-methoxy-1-methylethyl)acetamide (metolachlor); 2-chloro-1-(3-ethoxy-4nitrophenoxy)-4-(trifluoromethyl) benzene (oxyfluorfen); $N$-(1-ethylpropyl)-3,4-dimethyl2,6-dinitrobenzenamine (pendimethalin); $O$-(6-chloro-3-phenyl-4-pyridazin-yl) $S$ octylcarbonothioate (pyridate); 2,6-dinitro- $N, N$-dipropyl-4-(trifluoromethyl)benzenamine (trifluralin).
\end{abstract}

The unique maritime climate of western Washington, characterized by dry summers and mild winters, permits overwintering and production of high-quality cabbage seed. Thus, Washington State is the dominant cabbageseed-growing area in the world, producing $>50 \%$ of the world supply (Gabrielson and Pelter, 1989).

Weed competition may reduce seed yield in cabbage by $>50 \%$ (Al-Khatib and Libbey, 1992). In addition, weeds present at harvest increase mechanical damage to cabbage seed and reduce harvest efficiency. Weeds also can reduce cabbage seed quality by interfering with processing operations. Seeds of certain weeds, such as wild mustard [Brassica kaber (DC.) L.C. Wheeler], catchweed bedstraw (Galium aparine L.), and redstem filaree [Erodium cicutarium (L.) L'Her. ex Ait], are the same size as the cabbage seed, making separation during cleaning operations difficult. Cabbage seed contaminated with weed

Received for publication 2 Mar. 1995. Accepted for publication 13 June 1995. A/CSS paper 9406-10, project 13K-3419-4940, Washington State College of Agriculture and Home Economics Research Center. This research was supported in part by a grant from the Northwest Agriculture Research Foundation. The cost of publishing this paper was defrayed in part by the payment of page charges. Under postal regulations, this paper therefore must be hereby marked advertisement solely to indicate this fact.

${ }^{1}$ Weed Scientist. To whom reprint requests should be addressed.

${ }^{2}$ Research Technologist.

${ }^{3}$ Research Associate.

HortScience, Vol. 30(6), October 1995 and winter annual weeds during their lifecycle.
Proper cultural practices, in conjunction with using 2-[1-(ethoxyimino)butyl]-5-[2(ethylthio)propyl]-3-hydroxy-2-cyclohexen1 -one (sethoxydim) or $( \pm)-2-\{4-[[5-$ (trifluoromethyl)-2-pyridinyl]oxy]phenoxy $\}$ propanic acid (fluazifop) effectively controls grasses in cabbage fields. However, methods to control broadleaf weeds in cabbage seed fields are limited by lack of effective labeled herbicides.

Trifluralin, oxyfluorfen, 2-[(2chlorophenyl)methyl]-4,4-dimethyl-3isoxazolidinone (clomazone), dimethyl 2,3,5,6-tetrachloro-1,4-benzenedicarboxylate (DCPA), N,N-diethyl-2-(1-naphthalenyloxy) propanamide (napropamide), clopyralid, and pyridate controlled several broadleaf weeds in processing cabbage (Bellinder and Warholic, 1988; Bellinder et al., 1989; Bhowmik and McGlew, 1986; Cowgill and Majek, 1991; Granbowski and Hopen, 1984; Kee, 1985; Marion et al., 1985; Scott and Weston, 1989; Scott et al., 1995; Stamm and Ashley, 1980; Wallace and Bellinder, 1991), but to our knowledge, no research has evaluated herbicides for broadleaf weed control in cabbage grown for seed. Therefore, our objective was to evaluate the effect of same herbicides on broadleaf weeds and cabbage plants grown for seed.

\section{Materials and Methods}

The experiment was conducted during 1991-92 and 1992-93 growing seasons at Mount Vernon Research and Extension Unit, Mount Vernon, Wash., on a Skagit silty-loam soil (fine-silty, mixed, nonacid, mesic typic fluvaguents). Soil organic matter was $2.6 \%$ and $1.4 \%$ and soil $\mathrm{pH}$ was 5.9 and 6.7 in 1991 and 1992, respectively. Plots were naturally infested with a high population of common lambsquarters (Chenopodium album L.), shepherdspurse [Capsella bursa-pastoris (L.) Medic.], common chickweed [Stellaria media (L.) vill.], pineapple-weed [Matricaria

Table 1. Broadleaf weed control with herbicides at 70 and 140 days after transplanting (DAT ) in cabbage grown for seed from 1991 to 1992 and from 1992 to 1993 in Mt. Vernon, Wash.

\begin{tabular}{|c|c|c|c|c|c|}
\hline \multirow[b]{4}{*}{ Treatments } & \multirow{4}{*}{$\begin{array}{c}\text { Rate } \\
\left(\mathrm{kg}^{\circ} \mathrm{ha}^{-1}\right)\end{array}$} & \multicolumn{4}{|c|}{ Broadleaf weed control (\%) } \\
\hline & & \multirow{2}{*}{\multicolumn{2}{|c|}{$\frac{1991-92}{\text { DAT }}$}} & \multirow{2}{*}{\multicolumn{2}{|c|}{$\begin{array}{c}1992-93 \\
\text { DAT }\end{array}$}} \\
\hline & & & & & \\
\hline & & 70 & 140 & 70 & 140 \\
\hline \multirow[t]{3}{*}{ Pendimethalin } & 0.96 & 75 & 5 & 78 & 78 \\
\hline & 1.92 & 85 & 35 & 94 & 84 \\
\hline & 3.84 & 90 & 63 & 90 & 90 \\
\hline Oxyfluorfen & 0.54 & 60 & 20 & 91 & 78 \\
\hline Trifluralin & 0.84 & 80 & 0 & 68 & 63 \\
\hline Metolachlor & 3.36 & 0 & 0 & 26 & 0 \\
\hline \multirow{2}{*}{ Pyridate } & 0.5 & 75 & 0 & 50 & 18 \\
\hline & 1 & 83 & 0 & 58 & 20 \\
\hline \multirow{2}{*}{ Clopyralid } & 0.21 & 3 & 5 & 21 & 13 \\
\hline & 0.42 & 0 & 0 & 29 & 14 \\
\hline Trifluralin + oxyfluorfen & $0.84+0.54$ & 90 & 88 & 96 & 94 \\
\hline $\begin{array}{l}\text { Pendimethalin }+ \\
\text { clopyralid }\end{array}$ & $1.92+0.21$ & 90 & 28 & 94 & 92 \\
\hline $\begin{array}{l}\text { Oxyfluorfen + } \\
\text { clopyralid }\end{array}$ & $0.54+0.21$ & 67 & 23 & 93 & 78 \\
\hline Oxyfluorfen + pyridate & $0.54+0.50$ & 90 & 83 & 96 & 82 \\
\hline None, weedy control & & 0 & 0 & 0 & 0 \\
\hline None, weed-free control & & 100 & 100 & 100 & 100 \\
\hline $\mathrm{LSD}^{\mathrm{z}}$ & & 8 & 16 & 16 & 13 \\
\hline
\end{tabular}

${ }^{2}$ Mean separation within columns at $P \leq 0.05$ by Fisher's protected least significant difference. 
matricarioides (Less.) Porter)], hedge mustard [Sisymbrium officinale (L.) Scop.], common groundsel (Senecio vulgaris L.), redroot pigweed (Amaranthus retroflexus L.), henbit (Lamium amplexicule L.), and purple deadnettle (Lamium purpureum L.).

Plots consisted of one 4.5-m row with 10 plants. Greenhouse-grown plants of '59131218' hybrid cabbage were transplanted when they had four to five leaves (on 5 Sept. 1991 and 9 Sept. 1992). Cabbage plants were harvested for seed on 15 July 1992 and 20 July 1993. Treatments were replicated four times in a randomized complete-block design. Conventional tillage practices were followed; plants were monitored for insect and diseases and were treated according to Washington State Univ. guidelines.

Herbicides were applied with a tractormounted compressed-air sprayer. The sprayer was equipped with flat fan nozzles (8002LP; Sprayers Systems Co., Wheaton, Ill.) spaced $50 \mathrm{~cm}$ apart that delivered 140 liters.ha ${ }^{-1}$ at 103 $\mathrm{kPa}$ while traveling $3.2 \mathrm{~km} \cdot \mathrm{h}^{-1}$. Boom height was adjusted to $50 \mathrm{~cm}$ above the ground.

Applied pretransplanting (PRTR) on top of the soil were pendimethalin at $0.96,1.92$, and $3.84 \mathrm{~kg}$ a.i./ha, oxyfluorfen at $0.54 \mathrm{~kg} \cdot \mathrm{ha}^{-1}$, and trifluralin at $0.84 \mathrm{~kg} \cdot \mathrm{ha}^{-1}$, the latter being incorporated $5 \mathrm{~cm}$ deep with one pass of a rototiller. Applied posttransplant (POST) were (in $\mathrm{kg} \cdot \mathrm{ha}^{-1}$ ) pyridate at 0.5 and 1.0 , metolachlor at 3.36, and clopyralid at 0.21 . In addition, treatments included a sequential application of trifluralin (incorporated)/oxyfluorfen, pendimethalin/clopyralid, oxyfluorfen/ clopyralid, and oxyfluorfen/pyridate. POST applications of clopyralid and pyridate were made when cabbage plants were at nine to 12 leaves and weeds were at three to four leaves, whereas metolachlor was applied 2 weeks after transplanting but before weed emergence. Weedy and weed-free controls were included. Weed-free controls were maintained by handweeding as needed. All POST treatments, except metolachlor, included nonionic surfactant (X77 Spreader; alkylarylpolyoxethylene, glycols, free fatty acids, and isopropanol; Valent, Walnut Creek, Calif.) at $0.5 \%$ (v/v).

General broadleaf weed (shepherdspurse, common chickweed, pineapple-weed, and hedge mustard control) control and crop injury (plants effected) were visually evaluated on a percentage scale, $0=$ no control or crop injury and $100=$ complete control or all cabbage plants dead. The ratings were made every 14 days after transplanting (DAT) cabbage. Cabbage plants were observed biweekly for injury during the entire 1991-92 and 1992-93 growing seasons.

The population of cabbage was determined by counting the number of cabbage plants in each plot at 10 weeks after transplanting. Cabbage height was measured when plants were at the bud stage. Dry weight biomass of cabbage plants was determined at harvest. Plant samples were dried at $70 \mathrm{C}$ for 4 days and then weighed. Seed yield per plant was determined by dividing total seed yield per plot by the number of plants in the same plot, which varied from eight to 10 plants.
Weed control, crop injury, cabbage population, plant height, total biomass, and seed yields were subjected to analysis of variance, and means were compared with Fisher's protected least significant difference at $P \leq 0.05$. Visual estimates of crop injury and weed control were analyzed as raw data and after arcsinsquare-root transformation. Nontransformed data are presented.

\section{Results and Discussion}

Weed control. In 1992, all herbicides initially provided $>85 \%$ control of broadleaf weeds, except metolachlor and clopyralid, which control $<20 \%$ of broadleaf weeds (data not shown). At 70 DAT, the best broadleaf control was obtained with pendimethalin at 1.92 and $3.84 \mathrm{~kg} \cdot \mathrm{ha}^{-1}$, trifluralin + oxyfluorfen, pendimethalin + clopyralid, and oxyfluorfen + pyridate (Table 1). However, at 140 DAT, only trifluralin + oxyfluorfen and oxyfluorfen + pyridate controlled $>80 \%$ of broadleaf weeds. At the end of the growing season, only trifluralin + oxyfluorfen showed acceptable broadleaf weed control (65\% control).

In 1993, pendimethalin at 1.92 and 3.84 $\mathrm{kg} \cdot \mathrm{ha}^{-1}$, oxyfluorfen, trifluralin + oxyfluorfen, pendimethalin + clopyralid, oxyfluorfen + clopyralid, and oxyfluorfen + pyridate controlled $>90 \%$ of broadleaf weeds 70 DAT (Table 1). At 140 DAT, pendimethalin at 1.92 and $3.84 \mathrm{~kg} \cdot \mathrm{ha}^{-1}$, trifluralin + oxyfluorfen, pendimethalin + clopyralid, and oxyfluorfen + pyridate continued to control weeds. At the end of the growing season, broadleaf weed control was best with trifluralin + oxyfluorfen and pendimethalin + clopyralid (data not shown).

Broadleaf weed control at 140 DAT was better in 1993 than 1992 (Table 1). This difference may be attributed to an unusually cold

Table 2. Shepherdspurse (CAPBP), common chickweed (STEME), pineapple-weed (MATMT), and hedge mustard (SSYOF) control with herbicides 70 days after transplanting of cabbage grown for seed from 1991 to 1992 and from 1992 to 1993 in Mt. Vernon, Wash. ${ }^{\mathrm{z}}$

\begin{tabular}{|c|c|c|c|c|c|}
\hline \multirow[b]{3}{*}{ Treatments } & \multirow{3}{*}{$\begin{array}{c}\text { Rate } \\
\left(\mathrm{kg} \cdot \mathrm{ha}^{-1}\right)\end{array}$} & \multicolumn{4}{|c|}{ Control (\%) } \\
\hline & & \multicolumn{4}{|c|}{ Weeds } \\
\hline & & $\overline{\mathrm{CAPBP}}$ & STEME & MATMT & SSYOF \\
\hline \multirow[t]{3}{*}{ Pendimethalin } & 0.96 & 76 & 87 & 55 & 30 \\
\hline & 1.92 & 80 & 92 & 56 & 55 \\
\hline & 3.84 & 83 & 98 & 58 & 58 \\
\hline Oxyfluorfen & 0.54 & 95 & 45 & 90 & 75 \\
\hline Trifluralin & 0.84 & 5 & 100 & 5 & 2 \\
\hline Metolachlor & 3.36 & 58 & 5 & 40 & 0 \\
\hline \multirow[t]{2}{*}{ Pyridate } & 0.5 & 60 & 60 & 70 & 0 \\
\hline & 1.00 & 57 & 66 & 90 & 2 \\
\hline \multirow[t]{2}{*}{ Clopyralid } & 0.21 & 29 & 16 & 90 & 0 \\
\hline & 0.42 & 46 & 8 & 92 & 0 \\
\hline Trifluralin + oxyfluorfen & $0.84+0.54$ & 82 & 98 & 90 & 80 \\
\hline Pendimethalin+ clopyralid & $1.92+0.21$ & 74 & 93 & 100 & 60 \\
\hline Oxyfluorfen + clopyralid & $0.54+0.21$ & 84 & 55 & 100 & 80 \\
\hline Oxyfluorfen + pyridate & $0.54+0.50$ & 80 & 90 & 100 & 75 \\
\hline None, weedy control & & 0 & 0 & 0 & 0 \\
\hline None, weed-free control & & 100 & 100 & 100 & 100 \\
\hline $\operatorname{LSD}_{0.05^{y}}$ & & 38 & 19 & 15 & 21 \\
\hline
\end{tabular}

${ }^{\mathrm{z}}$ Mean 1991 to 1992 and 1992 to 1993.

yean separation within columns by Fisher's protected least significant difference.

Table 3. Shepherdspurse (CAPBP), common chickweed (STEME), pineapple-weed (MATMT), and hedge mustard (SSYOF) control with herbicides 140 days after transplanting of cabbage grown for seed from 1991 to 1992 and from 1992 to 1993 in Mount Vernon, Wash. ${ }^{2}$

\begin{tabular}{|c|c|c|c|c|c|}
\hline \multirow[b]{3}{*}{ Treatments } & \multirow{3}{*}{$\begin{array}{c}\text { Rate } \\
\left(\mathrm{kg} \cdot \mathrm{ha}^{-1}\right)\end{array}$} & \multicolumn{4}{|c|}{ Control (\%) } \\
\hline & & \multicolumn{4}{|c|}{ Weeds } \\
\hline & & CAPBP & STEME & MATMT & SSYOF \\
\hline \multirow{3}{*}{ Pendimethalin } & 0.96 & 64 & 53 & 47 & 29 \\
\hline & 1.92 & 56 & 81 & 60 & 54 \\
\hline & 3.84 & 77 & 86 & 70 & 43 \\
\hline Oxyfluorfen & 0.54 & 93 & 15 & 82 & 68 \\
\hline Trifluralin & 0.84 & 7 & 96 & 33 & 9 \\
\hline Metolachlor & 3.36 & 0 & 0 & 0 & 0 \\
\hline \multirow[t]{2}{*}{ Pyridate } & 0.5 & 3 & 2 & 50 & 25 \\
\hline & 1 & 12 & 0 & 53 & 12 \\
\hline \multirow[t]{2}{*}{ Clopyralid } & 0.21 & 4 & 2 & 92 & 12 \\
\hline & 0.42 & 3 & 0 & 93 & 0 \\
\hline Trifluralin + oxyfluorfen & $0.84+0.54$ & 92 & 92 & 93 & 88 \\
\hline Pendimethalin + clopyralid & $1.92+0.21$ & 61 & 75 & 100 & 72 \\
\hline Oxyfluorfen + clopyralid & $0.54+0.21$ & 87 & 24 & 100 & 71 \\
\hline Oxyfluorfen + pyridate & $0.54+0.50$ & 96 & 42 & 90 & 85 \\
\hline None, weedy control & & 0 & 0 & 0 & 0 \\
\hline Nonte, weed-free control & & 100 & 100 & 100 & 100 \\
\hline $\operatorname{LSD}_{0.05}{ }^{\mathrm{y}}$ & & 17 & 19 & 34 & 30 \\
\hline
\end{tabular}

${ }^{\mathrm{z}}$ Mean 1991 to 1992 and 1992 to 1993.

'Mean separation within columns by Fisher's protected least significant difference. 
winter in 1993, which slowed herbicide degradation in the soil (Walker, 1987). In addition, 1992-93 plots were heavily infested with henbit and purple deadnettle, which were susceptible to all herbicides, except metolachlor.

When herbicides were applied alone, shepherdspurse, common chickweed, pineapple-weed, and hedge mustard (which are the dominant broadleaf weeds in cabbage seed fields in the Pacific Northwest) responded differently to herbicides 70 DAT (Table 2). Oxyfluorfen and pendimethalin at 1.92 and $3.84 \mathrm{~kg} \cdot \mathrm{ha}^{-1}$ controlled $>80 \%$ of shepherdspurse. Trifluralin and pendimethalin at 3.84 $\mathrm{kg} \cdot \mathrm{ha}^{-1}$ gave perfect control of common chickweed. Pineapple-weed was not controlled with any herbicide, except oxyfluorfen, clopyralid, and the highest rate of pyridate. Hedge mustard was not controlled by any herbicide tested in this study.

Control of shepherdspurse, common chickweed, pineapple-weed, and hedge mustard was less at 140 DAT (Table 3 ) than at 70 DAT. This response was not surprising because the herbicides that we used break down relatively rapidly in the soil (Reyes and Zimdahl, 1989; Schlesselman and Lange, 1984; Smith and Aubin, 1989; Walker and Zimdahl, 1981; Zimdahl et al., 1984). Oxyfluorfen continued to control shepherdspurse. Trifluralin and the highest rate of pendimethalin controlled $96 \%$ and $86 \%$ of common chickweed, respectively. Pineapple-weed was not affected by herbicides, except clopyralid, which controlled $>90 \%$ of this species. Hedge mustard was not significantly controlled by any herbicide.

Broadleaf weed control with herbicide combinations was better than with herbicides applied alone (Table 1). This superior broadleaf weed control with combinations was due to the complementary weed control spectrum of each herbicide in the combination (Tables 2 and 3 ). The best broadleaf control was with the trifluralin + oxyfluorfen combination. In addition, this combination provided additive effects on many broadleaf weeds, including hedge mustard.

Cabbage injury. Visible symptoms of herbicide injury on cabbage ranged from moderate to slight. All herbicides injured cabbage in both growing seasons (data not shown). When herbicides were applied alone, pendimethalin injured cabbage the most; trifluralin and metolachlor injured cabbage the least. However, injury appeared to be transitory; as the crop recovered, and plants looked normal at the bud stage. Cabbage population, flowering date, and plant height were not affected by herbicides (data not shown).

Pendimethalin caused injury symptoms 30 DAT, with maximum injury symptoms 70 DAT; however, plants recovered from these symptoms by 100 DAT and 170 DAT when pendimethalin was applied at 1.92 and 3.84 $\mathrm{kg} \cdot \mathrm{ha}^{-1}$, respectively (data not shown). Pendimethalin caused stunting, and as the degree of injury increased, plants became dark green and leaves occasionally were distorted, crinkled, and cupped downward. The intensity of these symptoms was greater, and the number of leaves affected was higher when the higher pendimethalin rate was used.

Oxyfluorfen injury symptoms were minimal and similar to those reported earlier (Bhowmik and McGlew, 1986; Granbowski and Hopen, 1984). Symptoms were plant stunting, bleaching, and necrotic spotting. However, cabbage plants slowly recovered from injury symptoms and were normal 140 DAT. These results agree with earlier work that showed cabbage plants recovered from initial oxyfluorfen injury (Bhowmik and McGlew, 1986).

Within 5 to 7 days after applying pyridate at $1 \mathrm{~kg} \cdot \mathrm{ha}^{-1}$, chlorotic and necrotic spots and leaf crinkling and distortion were evident on cabbage. Symptoms were similar but slight and developed more slowly when pyridate was applied at $0.5 \mathrm{~kg} \cdot \mathrm{ha}^{-1}$. Only the high rate of pyridate showed significant injury on cabbage 70 DAT. Cabbage plants had completely recovered from pyridate injury 90 DAT.

Cabbage was visibly injured by clopyralid 5 days after treatment. Injury symptoms were the worst 15 days after treatment then gradually diminished. Plants appeared normal by 70 DAT. Trifluralin and metolachlor slightly injured cabbage by 50 DAT. Symptoms were plant stunting and leaf distortion; however, plants had recovered from these symptoms by 70 DAT.

All herbicide combinations, except trifluralin + oxyfluorfen, moderately injured cabbage plants by 70 DAT. Oxyfluorfen + clopyralid, pendimethalin + clopyralid, and oxyfluorfen + pyridate injured $6 \%, 7 \%$, and $10 \%$ of the plants, respectively. However, plants rapidly recovered from injury and appeared normal at bud stage.

Cabbage productivity. Weed competition reduced total biomass and seed yield of cabbage $>50 \%$ (weedy vs. weed-free controls; Table 4). Cabbage biomass and seed yield increased as the level of broadleaf weed control increased $(r=0.90$ and 0.91 , respectively). Total biomass and seed yield did not differ between the weed-free control, and pendimethalin at 1.92 and $3.84 \mathrm{~kg} \cdot \mathrm{ha}^{-1}$, trifluralin +

Table 4. Biomass and seed yield in cabbage plants grown for seed from 1991 to 1992 and from 1992 to 1993 as affected by herbicides in Mount Vernon, Wash. ${ }^{2}$

\begin{tabular}{lcrr}
\hline & Rate & \multicolumn{2}{c}{ Yield (g/plant) } \\
\cline { 2 - 4 } Treatments & $\left(\mathrm{kg} \cdot \mathrm{ha}^{-1}\right)$ & Biomass & Seed \\
\hline Pendimethalin & 0.96 & 708 & 55 \\
& 1.92 & 948 & 74 \\
Oxyfluorfen & 3.84 & 964 & 70 \\
Trifluralin & 0.54 & 901 & 61 \\
Metolachlor & 0.84 & 502 & 36 \\
Pyridate & 3.36 & 530 & 37 \\
& 0.5 & 502 & 41 \\
Clopyralid & 1.00 & 693 & 50 \\
& 0.21 & 442 & 40 \\
Trifluralin + oxyfluorfen & 0.42 & 451 & 30 \\
Pendimethalin +clopyralid & $0.84+0.54$ & 1188 & 82 \\
Oxyfluorfen + clopyralid & $1.92+0.21$ & 1072 & 74 \\
Oxyfluorfen + pyridate & $0.54+0.21$ & 901 & 64 \\
None, weedy control & $0.54+0.50$ & 1205 & 70 \\
None, weed-free control & & 469 & 33 \\
LSD ${ }_{0.05}{ }^{y}$ & & 1170 & 78 \\
\hline Mean & & 275 & 16 \\
\hline
\end{tabular}

${ }^{\text {zMean }} 1991$ to 1992 and 1992 to 1993.

yMean separation within columns by Fisher's protected least significant difference.

oxyfluorfen, pendimethalin + clopyralid, and oxyfluorfen + pyridate treatments.

Although several herbicides injured cabbage, the injury was temporary and did not reduce total biomass and seed yield compared to weed-free plots. In general, cabbage seed yields were highest in herbicide-treated plots that initially had the most crop injury. We attribute this response to superior broadleaf weed control and rapid recovery of cabbage plants from injury symptoms.

PRTR treatments of pendimethalin at 1.92 and $3.84 \mathrm{~kg} \cdot \mathrm{ha}^{-1}$, trifluralin + oxyflourfen, and sequential treatment of pendimethalin followed by POST application of clopyralid, or oxyfluorfen followed by postemergence application of pyridate or clopyralid should provide adequate broadleaf weed control with no adverse effect on cabbage growth and seed yield.

\section{Literature Cited}

Al-Khatib K. and C. Libbey. 1992. Weed control in vegetable seed crops. Proc. Wash. Hort. Assn. 83:30-35.

Bellinder, R. and D.T. Warholic. 1988. Evaluation of acetanilide injury and potential for yield reduction in cabbage, Brassica oleracea $\mathrm{L}$. Weed Technol. 2:350-354.

Bellinder, R.R., D. Wilcox-Lee, A. Senesac, and D.T. Warholic. 1989. Response of early-maturing cabbage (Brassica oleracea var. Capitata) to metolachlor. Weed Technol. 3:463-466.

Bhowmik, P.C. and E.N. McGlew. 1986. Effect of oxyfluorfen as a pretransplant treatment on weed control and cabbage yield. J. Amer. Soc. Hort. Sci. 111:686-689.

Cowgill, W.P., Jr., and B.A. Majek. 1991. Effectiveness of clopyralid for the control of broadleaf weeds in vegetable crops. Proc. Northeastern Weed Sci. Soc. 45:27-29.

Gabrielson, R.L. and G.Q. Pelter. 1989. Vegetable seeds for the nation and the world. Washington Land People 3:2-7.

Granbowski, J.M. and H.J. Hopen. 1984. Evaluation of oxyfluorfen formulations for cabbage weed control. J. Amer. Soc. Hort. Sci. 109: 539 543.

Kee, W.E. 1985. Herbicide evaluation for spring
HortScience, Vol. 30(6), October 1995 
and fall cole crops. Proc. Northeastern Weed Sci. Soc. 39:142-146.

Marion, G.R., R.D. Ilnicki, C. Kupatt, and D.B. Vitolo. 1985. Weed control in transplanted cole crops with some new herbicides. Proc. Northeastern Weed Sci. Soc. 39:147-150.

Reyes, C.C. and R.L. Zimdahl. 1989. Mathematical description of trifluralin degradation in soil. Weed Sci. 37:604-608.

Schlesselman, J.T. and A.H. Lange. 1984. Influence of irrigation timing on the preemergence activity of oxyfluorfen. Proc. Western Soc. Weed Sci. 37:63-67.
Scott, J.E. and L.A. Weston. 1989. Clomazone tolerance and weed control in selected cole crops. Proc. Northcentral Weed Sci. Soc. 44:80-81.

Scott, J.E., L.E. Weston, and R.T. Jones. 1995. Clomazone for weed control in transplanted cole crops (Brassica oleracea). Weed Sci. 43:121-127.

Smith, A.E. and A.J. Aubin. 1989. Persistence studies with the herbicide clopyralid in prairie soils at different temperatures. Bul. Environ. Contaminant Toxicol. 42:670-675.

Stamm, G.K. and R.A. Ashley. 1980. Weed control in transplanted cabbage, cauliflower, and broccoli. Proc. Northeastern Weed Sci. Soc. 34:201-203.
Walker, A. 1987. Herbicide persistence in soil. Rev. Weed Sci. 3:1-17.

Walker, A. and R.L. Zimdahl. 1981. Simulation of the persistence of atrazine, linuron, and metolachlor in soil at different sites in U.S.A. Weed Res. 21:255-265.

Wallace, R.W. and R.R. Bellinder. 1991.Clopyralid and pyridate for postemergence broadleaf weed control in crucifers. Proc. Northeastern Weed Sci. Soc. 45:87.

Zimdahl, R.L.,P.Catizone, and A.C. Butcher. 1984. Degradation of pendimethalin in soil. Weed Sci. 32:408-412. 